\title{
Articulating difference: the problem of the Other in International Political Economy
}

\author{
E. Fuat Keyman \\ Department of Political Science and Public Administration, \\ Bilkent University
}

\begin{abstract}
This paper demonstrates that advancing our understanding of international political economy (IPE) entails posing the question of otherness and difference as an object of theoretical and historical inquiry. It suggests that the discourses of postmodernism, feminism, and postcolonial criticism directly contribute to IPE by locating the problematic of identity/difference at the center of the dialectic of social change. By pinpointing the strength and the problematic nature of each of these discourses, it argues that the reconstruction of IPE based on the recognition of difference requires 'an empathetic cooperation' among these discourses as a precondition for the creation of a dialogical interaction between theoretical discourse and subject-positions to whom it is addressed.
\end{abstract}

\section{KEYWORDS}

Difference; empathetic cooperation; feminism; postmodernism; postcolonial; the Other.

Our period is not defined by the triumph of technology for technology's sake, as it is not defined by art for art's sake, as it is not defined by nihilism. It is action for a world to come, transcendence of its period - transcendence of self which calls for epiphany of the Other.

Emmanuel Levinas

\section{INTRODUCTION}

As a discipline in constant interaction with the Other(s), International Political Economy (IPE) cannot afford to be without the ability to resolve the critical issues that otherness and difference raise, issues such as

(C) 1995 Routledge $0969-2290$ 
how to approach and represent different cultures and subjectivities. Paradoxically however, the more IPE is derived from a strong western rationalist and universalistic posture, the more it reduces the 'ethical space' for the Other(s) to represent themselves independent of western universalism, in their own cultural specificity and with ownership of their history. In fact, a quick glance at what Murphy and Tooze (1991) have termed 'the IPE orthodoxy' reveals that though the need to know the Other is, and has always been, strongly emphasized, the dominant mode in which such knowing is realized has been the accumulation of diverse 'empirical' knowledge of other peoples, other nations, other regions, and other cultures, with a taken-for-granted assumption that more knowledge automatically ensures and produces a better understanding of the Other. The problem however is that accounting for the Other to discover cultural similarities and differences leads other cultures to become counted within the dominant scientific discourse (the reproduction of western universalism) and also to maintain the privileged role of the western self as a rational, Cartesian modern cogito to define the course of historical development as progress. ${ }^{1}$

Nevertheless, there is an increasing awareness in the domain of IPE of how the appropriation of the Other as an empirical/cultural object has led to the justification of western universalism as global modernity (Fukuyama, 1989), which in turn marks the exclusionary character of the IPE orthodoxy as an occidental and gendered grand narrative of modernity. The three evident voices of this awareness are namely those of the emerging new discourses of postmodernism, feminism and postcolonial criticism, all of which share the common concern with what Rob Walker has called 'a highly problematic character of political identity. in the modern world' (Walker, 1992: 182). To emphasize the problematic character of political identity is to challenge the unitary conception of the modern self, which involves an internal critique of modernity in terms of its constitutive units and its universalizing mode of operation. In this sense, to critique the IPE orthodoxy in terms of its tendency to dissolve the Other is to initiate an assault on its unfolding essence, its privileged identity, that is, in Richard Ashley's terminology, the man as the modern sovereign self (Ashley, 1989: 259-322). The problematization of modernity thus becomes the ground on which both to reexamine the established epistemological and ontological procedures of IPE and to provide an 'ethical space' for the Other to speak with its own cultural specificity.

In this context, the argument made in this paper is twofold. First, an attempt to advance our understanding of IPE entails posing the question of otherness and difference as a serious problem, or to put it precisely, as an object of theoretical and historical inquiry. In other words, otherness and difference, as David Harvey argues (1993: 3), should not be treated as 'something to be added on' but 'as something that should be omnipresent 
from the very beginning' in any attempt to grasp the functioning of IPE. In this respect, the paper suggests that the discourses of postmodernism, feminism and postcolonial criticism directly contribute to IPE (a) by locating the problematic of identity/difference at the center of the dialectic of social change; (b) by breaking radically with the appropriation of the Other(s) as an empirical/cultural object and making a call for the necessity to treat the Other(s) as difference; and (c) by going beyond the conception of culture as shared meaning and regarding it as a signifying practice integral to the process of interpellation of individuals as subjects. Second, by pinpointing the strength and the problematic nature of each discourse the paper attempts to demonstrate that the reconstruction of IPE based on the recognition of difference requires a construction of a dialogical interaction, or as Christine Sylvester (1994) calls it, 'an empathetic cooperation' among the discourses of postmodernism, feminism, and postcolonial criticism. Such empathetic cooperation is founded upon the idea that each discourse listens to the others, learns from the others and reconstructs itself on the basis of the crucial insights provided by the others. As Sylvester (1994: 165) puts it,

Empathy leads to listening to the excluded, listening to their sense of the good, knowing that they will present a fractured and heavily contested discourse because they have been simultaneously inside and outside a master narrative. Cooperation comes in re-scripting agendas to reflect the subjectivities that have been etched into the identities of empathetic listeners.

The empathetic cooperation among these discourses is key to breaking with the patriarchal and Eurocentric operation of the IPE orthodoxy, as well as to engaging in a dialogical interaction with different cultures, different histories and different empirical referents.

In order to substantiate these arguments, this paper will move in two carefully circumscribed steps. First, it will sort out four different ways in which the Other(s) have been approached in the realm of IPE and will suggest that there are two different conceptions of culture that lead to such approaches. Given the fact that classifications and categorizations always run a risk of being highly problematic and encompassing, my intention here is simply to highlight the importance of postmodernism, feminism, and postcolonial criticism in both drawing our attention to the question of otherness and difference and providing us with important conceptual tools by which to deal with that question. Second, the paper will discuss the utility of postmodernism, feminism, and postcolonial criticism in terms of their own critiques of modernity and their own understandings of difference. It is on this discussion that a call for empathetic cooperation among them as a necessary condition for an adequate analysis of difference will be based. 


\section{THE APPROPRIATION OF THE OTHER AND THE DIFFERENT PARADIGMS OF CULTURE}

By mapping the study of IPE, one can discern four different modes of appropriation of otherness:

1 The Other as an empirical/cultural object. Approached this way, the Other is regarded as an object which can be accounted for through collecting facts. Here the intention is to explain the Other by providing so-called objective and factual knowledge about it. It should be noted immediately that this notion of the Other is an outcome of the cultural essentialism embedded in the modernizationist dichotomy drawn between modern (western) and traditional (non-western). In this respect, although it is assumed that a search for objective and factual knowledge leads to a better understanding of other subject positions and cultures, such a search is embedded in an a priori characterization of the Other as a fixed entity, a non-western subject which lacks essentially what the modern subject has, i.e., rationality, modernity, reason, progress. In fact, as Asad (1991: 314) correctly points out within the context of anthropology, what objective and factual knowledge provides is a substantiation of the already established classification of non-western culture in accordance with 'Europe's story of triumph as progress'. Thus, the Other becomes defined with respect to what it is not rather than what it is. It constitutes a cultural object whose condition of existence reveals a lack of everything the modern self possesses. It is approached from within the privileged and universal category of the modern self as a rational thinking subject and is represented as the mirror image of that self. The illustrative examples of this approach in the realm of IPE are those of neorealism and theories of modernization and political development. In their epistemological procedures, Marxist theories of imperialism (Brewer, 1980) and the Wallersteinian world-systems theory also employ the conception of the Other as an empirical/cultural object, although they aim to resist the globalization of modernity as progress. Their universalistic claims to knowledge make use of the same binary dichotomy between modern and traditional, which makes them unable to recognize the very discursive construction of global modernity through the process of othering.

2 The Other as being. Employed in interpretive and existentialist discourses, the Other as being refers to 'the underground' of the modern self, that which contributes to the constitution of the self. An interpretivist or existentialist not only writes about the Other but also attempts to discover new relationships to the Other for exploring the cultural and historical quandaries of his/her 'self'. Employed in neo-dependency discourse (Cardoso and Faletto, 1979), the Gramscian 
theory of international relations (Gill, 1993), theories of international society (Bull, 1984; Rengger, 1989; Neumann and Welsh, 1991) and the Habermasian critical international relations theory (Linklater, 1990), this conception of the Other breaks radically with both the empiricist collection of facts and the cultural dissolution of the Other into the privileged modern self. However, by regarding the Other as an historical being, as a 'real' historical existence, both interpretive and existential discourse operate in the regime of modernity and maintain the self/ Other opposition.

3 The Other as a discursive construct. Viewed in this way, the Other constitutes 'an object of knowledge' constructed by various discourses and institutions. In his influential book, Orientalism, Edward Said (1978) shows how the entity called the 'Orient' was constructed, even produced, during the post-Enlightenment period, as the Other in such a way that 'European culture gained in strength and identity by setting itself off against the Orient as a sort of surrogate and even underground self'. On the basis of the epistemological and ontological distinction between the Orient and the Occident, the oriental Other was constructed and functioned as an integral part of European material civilization and culture. This conception of the Other brings about an epistemological and philosophical break with the modernist conception of the self both by rejecting the historicist account of the subject as an historical being and by relocating the question of the Other into the system of representation.

4 The Other as difference. Although Said's attempt to unearth the discursive character of the Other produces a significant breakthrough, it does not say much about the oriental Other in itself. This is a result of Said's overpreoccupation with the discursive construction of the Orient as an object of knowledge by which to construct a binary dichotomy between oriental and occidental. In other words, in Said's attempt, the oriental Other becomes a totalizing and homogenous construct which does not permit understanding of the construction of the oriental subject-positions. An understanding of the Other as a (post-) colonial identity requires an account of, or a problematization of, that identity in itself. This critique of Said leads to the conception of the Other as difference which allows for a consideration of the complex structures of cultural and national identity. Hence the Other as difference emphasizes the relational character of the self and the Other, allows room for a critical examination of the mutual dependence between colonizer and colonized, and shifts the focus to the question of identity/difference, all of which make possible a careful deconstruction of the self/the Other binary opposition as the basis of cultural essentialism of modernity (Laclau, 1992). Postmodernism, feminism, and postcolonial criticism resist such opposition, regard identity in relation to difference, and thus 


\section{ARTICULATING DIFFERENCE}

employ a relational understanding of identity as the basis of the recognition of the Other as difference.

These conceptions of the Other can be said to be embedded in, or emerge from within, two competing paradigms of culture in sociological and anthropological discourses. It is, in fact, these paradigms of culture which dictate the way in which the Other is appropriated. ${ }^{2}$ The first paradigm, which can be called 'the sociological/anthropological paradigm', has its roots in what Robertson terms 'the Gemeinschaft-Gesellschaft problematic' and conceives of culture as the shared values and meanings with which individual subjects interact with one another in a given historical period. Although these shared values and meanings appear to. imply that there are cultural differences between different nations, classes, or groups, once they are incorporated into the Gemeinschaft-Gesellschaft problematic, they operate as social totalities, that is, as cultural formations of different historical periods, such as modern and traditional. In this sense, culture refers to a 'state of being', constituted by certain shared values and meanings, and gives expression to the view of history as an unilinear historical development towards the highest point of civilization at which Europe has arrived with its modernity. Thus Europe, or modern society, with its Cartesian modern rational self, becomes the primary point of reference, the universal vantage point, for the study of culture as it dictates the emergence of modern society as a transition from Gemeinschaft to Gesellschaft. The anthropological paradigm of culture thus functions as a Eurocentric metanarrative by appropriating the Other as an empirical and cultural object, a state of being, whose condition of existence is read off from the modern self.

The second paradigm, which can be called 'the structuralist/post-structuralist paradigm', regards culture as a 'practice' rather than a state of being. More specifically, culture refers to a signifying practice by which meanings and values are constructed and exchanged within a given space. Approached in this way, the effects of culture as a practice in the production and reproduction of social relations, or the meaning of cultural practices, is taken to be the key to understanding what culture is. Althusser's concept of interpellation as an expression of the constitution of individuals as subjects, Lévi-Strauss's call for the need to analyze the life of signs operating in social totalities, Foucault's conception of discourse, and Derrida's notion of 'differance', are all produced to delineate the effects of cultural practices as signifying practices (Hall, 1992: $252-60$ ). Central to this understanding of culture in terms of its effects is the suggestion that language functions not simply as a medium of communication, but, more important, as integral to the constitution of individuals as subjects, insofar as it is through language that communication is made possible and objects are given meaning. Thus, in Course of General 
Linguistics, De Saussure (1978) argues that language should be considered a system of signs in which a holistic combination of two structural elements, namely the signifier and signified, is socially constructed. In this construction, as Saussure points out, what is significant is that meaning given to objects is always relational, that is, in order for different terms to have a meaning, they carry differences as a relation between them. Meaning in this sense emerges from the relation of difference between the different terms or objects within a system of signs. To illustrate this relationality, Saussure gives the example of the words 'day' and 'night', and suggests that it is the difference between them that makes it possible for them to carry a meaning. Likewise, neither 'modern' nor the 'modern self' could have an internally constructed meaning without their opposites, 'traditional' or 'the Other'. This implies that the exchange of meanings and values within a given space is realized through language and that cultural practices are in fact signifying practices that give meaning to objects through difference. The important conclusion that can be extrapolated here is that if meaning is relational and depends upon difference, established between objects, then the stability of the modern self as a privileged and universal point of reference can only be realized in relation to its Other. This means not only that the legitimacy of the universal character of Gesellschaft as modern society can only be achieved and maintained through the construction of the non-modern as its mirror image, but also that identities are relational and constructed in relation to difference.

At the theoretical level, regarding the Other as difference and understanding culture as a signifying practice constitutes a necessary condition for the reconstruction of IPE in a way that directly addresses the question of otherness. Herein lies the significance of postmodernism, feminism, and postcolonial criticism for IPE. These discourses are the three most successful forms of representation of the Other that are relevant to IPE as well as to international relations theory. Yet, as will be apparent in what follows, all still have their own particular difficulties, which can be resolved by creating an empathetic cooperation among them.

\section{POSTMODERNISM AND DIFFERENCE}

Postmodern discourse relies on the argument that modernist grand narratives, such as the autonomous subject, grand theory, and the unifying belief in progress, along with their culturally essentialist metanarrative of modernity, are undergoing substantial challenges and serious criticism, both of which have occurred as a result of 'changes in our international, intertextual, inter-human relations' (Der Derian and Shapiro, 1989: ix). According to Der Derian and Shapiro, these challenges and changes constitute 'the postmodern moment', in which 'objective reality is displaced 
by textuality; modes of production is supplanted by modes of information; representation blurs into simulation; imperialism gives way to the Empire of Signs'. Postmodernism thus represents a moment of putting into question the legitimacy of modernist narratives and an attempt to recognize difference. Underlying this argument is the idea that postmodernism is an instance of 'simulation' in which an aggregate of free-floating signifiers enjoy their unending playfulness, thereby rendering unstable the centered coherence of modernity and creating, as a result, the dissolution of the modernist imaginary of politics based on a privileged political identity (Ashley and Walker, 1990: 260-2). Thus, by employing the conception of culture as a signifying practice, postmodern discourse attempts to deconstruct the culturally essentialist functioning of modernity, gives voice to identities which have been marginalized and subjected to the process of othering, such as gender, race, ethnicity, and demonstrates a new vision based on the recognition of, and sensibility to, difference.

It should be recognized, however, that postmodern discourse in its deconstructive operation faces a crucial dilemma because it constitutes a knowledge embedded in western modernity which it aims to radically oppose. In other words, although it aims at providing a radical critique of what Derrida calls 'a certain fundamental Europeanization of world culture', in which 'the white man takes his own mythology, IndoEuropean mythology, his own logos, that is, the mythos of his idiom, for the universal form of that he must still wish to call Reason' (Derrida, 1982: 213), this critique is essentially directed at displaying the Eurocentric character of western modernity and its culturally essentialist operation. It is in this sense that deconstructing modernity in such a way to show its cultural essentialism would not necessarily lead to the reconceptualization of modernity from the lenses of the Other(s) on behalf of which postmodern discourse speaks. Two points are worth emphasizing. First, as Sangari has pointed out, it would be a mistake to universalize as everybody's crisis the crisis of meaning with which postmodernism is so preoccupied. That is to say, one should recognize that there are different modes of de-essentialization which are socially and politically grounded and mediated by separate perspectives, goals, and strategies for change in other countries' (Sangari, 1987: 184). For example, the postmodern rejection of such terms as truth, meaning, authority as logocentric categories could be an empirical referent for those who have been subjugated to the practices of domination. As Tapping (1989: 11) suggests,

[l]and claims, racial survival, cultural revival: all these demand an understanding of and response to the very concepts and structures which post-structuralist academicians refute in language games, few of which recognize the political struggles of real peoples outside such discursive frontiers. 
Second, the postmodern deconstruction of modernity in its refutation of humanism declares 'the death of the subject'. The universalization of such a declaration as an indicator of the crisis of meaning and a vantage point from which to initiate resistance in a non-humanist mode, however, could easily result in not only the non-recognition of cultural and political specificities of different cultures as well as different subject positions, such as race, gender and colonial, but also, and more important, the imposition of the postmodern deconstructive practice as the only plausible mode of resistance. As shall be seen, this tendency in postmodernism has led, for example, postcolonial criticism to characterize postmodernism as a 'complement' to the western domination over the rest of the world. Postcolonial criticism argues in this respect that there is a tendency in the postmodern discourse to ignore the crucial difference between the western subject and the colonial subject, which arises from the historical specificity of the colonized Other, that is, the role of imperialism in the constitution of the colonial subject. This difference has an important consequence in terms of the construction of political strategies against the grand narratives of modernity. As Hutcheon (1989: 151) points out, in postmodernism, what is at stake is the subject constituted within humanism and its essentialist mode of operation, which gives rise to a political agenda against such humanism. The colonial subject on the other hand is the colonized one whose condition of existence involves imperialism, which requires a different political agenda and a different object of analysis. However, this crucial difference is put on hold by the postmodernist discourse to reproduce and universalize the anti-humanist rhetoric of the 'death of the subject' as the only possibility of resistance to grand narratives. Thus, as hooks (1990: 24) asserts,

postmodernist perspective, most powerfully conceptualized as a 'politics of difference', [which] talks the most about heterogeneity, the decentred subject, declaring breakthroughs that allow a recognition of difference, still directs its critical voice primarily to a specialized audience that shares a common language rooted in the very master narrative it claims to challenge.

Hence, the colonial subject finds herself 'on the outside of the discourse looking in'. Underlying these two critical points about postmodern discourse is the recognition that the postmodern notion of difference is too abstract, due to its heavy philosophical and textual basis, to be used as a productive strategy against the exclusionary operation of western modernity.

It should be noted, however, that the recent emergence of what can be called 'a constructivist mode' in postmodern discourse also recognized the problematic and the self-restricted nature of deconstruction. In his critique of deconstruction, Connolly (1991:55) for instance has characterized 
deconstructive mode as a form of theoretical postponism which reveals 'the inability to establish secure epistemological grounds for a theory with an obligation to defer infinitely the construction of general theories of global politics'. Thus, Connolly suggests that postmodernism should go beyond theoretical postponism by treating deconstructive and constructive modalities as intertwined elements by the aid of which one could interpret world politics. Connolly's suggestion is predicated on an attempt first to approach modernity as a process of othering and second to put into service the problematic of identity/difference as a contribution to 'a general perspective that might support reconstitution of aspects of international life'. Der Derian's genealogical study of diplomacy (1987, 1991), Campbell's significant interpretive reading of security discourse and the Gulf War (1992, 1994), Walker's critical analysis of sovereignty and political community (1993), to name a few, are illustrative examples of the reconstruction of aspects of international life through the problematic of identity/difference. However, to what extent the constructivist mode in postmodern discourse moves away from the abstract notion of difference and establishes an empathetic relation with the Other(s) is determined by the degree to which it opens itself to different subjectivities, different histories, and different empirical referents. In other words, although the constructivist mode is of significance in 'construct[ing] alternative hierarchies that support modifications in relations between identity and difference' (Connolly, 1991: 57), its ability to do so depends upon its attempt to engage in empathetic cooperation with feminism and postcolonial criticism.

\section{FEMINISM AND SITUATING DIFFERENCE}

The feminist critique of modern grand narratives and its call for the recognition of difference rests upon an attempt to perceive history from 'the lenses of women' in such a way as to articulate theoretically the emancipatory aspirations of women. Thus, by resisting the codification of the category of woman as the silenced, oppressed, and peripheralized Other of the modern, sovereign male self, feminist discourse means not only critique but also the construction of a political subjectivity, enabling of collective action towards women's liberation. In other words, the feminist deconstruction of modernity takes the woman as its point of departure and exposes the patriarchal character of modernity and its totalizing operation in privileging the essentially masculinist concept of reason. Rejecting totalities and totalizing procedures and embracing temporalities and difference, feminist discourse develops an understanding of women's experiences as a way of resisting the hegemonic and patriarchal construction of human knowledge (Benhabib, 1992; Butler, 1990). Thus, what feminist discourse attempts to do is to rewrite history to make woman visible, 
reconceptualize reason to make it an irreducibly plural concept, to reconstruct human knowledge to make it engendered, to de-essentialize identity to show the destructive nature of the patriarchal modern self, and to construct a political subjectivity to make feminism the theoretical articulation of the emancipation and liberation of women.

An important implication of perceiving history from 'the lenses of women' is the apparent 'tension' in the connection between postmodernism and feminism. On the one hand, feminism allies with postmodernism in its critique of and its voiced skepticism toward the essentialist character of modernity. On the other hand, however, despite this similarity, feminist discourse differs from postmodernism, for the feminist critique of modernity does not involve a postmodern announcement of the death of the subject. Instead such a critique is designated around the central feminist concern with the question of the emancipation of women from existing power and domination relations. In this sense, with its orientation toward emancipation, as well as in its origin, feminist discourse constitutes a 'modern' project. According to Hekman (1990), this paradox that arises from the fact that feminist discourse is both modern and postmodern gives rise to what she calls 'an uneasy alliance' between feminism and postmodernism. It is uneasy in that feminism aims from the outset of its critique of modernity both to unmask the working of patriarchy in the subject's constitution by social orders and codes and to 'engender' such constitution.

As Peterson (1992: 1) argues, within the context of international relations theory, that '[r]eframing traditional constructs - states, sovereignty, political identity, security - through feminist lenses ... not only reveals how IR [international relations] is gendered but also explores the implications of that gendering', that is, 'the deconstruction of gender-biased knowledge claims and the reconstruction of gender-sensitive theory' as constitutive of the feminist dual agenda. What postmodern discourse does not do is to revise international relations theory through an 'explicit investigation of gender issues', for this would contradict its critique of totality and its denial of the possibility of constructing a systemic alternative. But, as Grant (1991: 19) has correctly argued, as postmodernism restricts itself only with deconstruction, it 'repeats many of the habits of gender bias'. Likewise, Sylvester (1994: 164-6) suggests that postmodernism's relation to feminism is based upon sympathy as a 'more distanced, socially correct response' rather than empathy as 'the capacity to participate in another's ideas and feelings', which results in the refusal by postmoderism of attempting 'to apply insights from contemporary feminist theory directly to the theory of international relations'. It is for these reasons, feminist discourse attempts to move beyond postmodern deconstruction to develop gender-sensitive theory as a means by which to problematize and decenter political identity. 
To recognize and challenge the gender bias in the existing theories of international relations, for feminist discourse, goes hand in hand with the recognition of the category of women as a crucial site of knowledge about international relations. In this context, Sharoni (1993: 5) argues that

we need to explode the artificial distinctions between 'women's issues' and 'international politics' by making topics such as the social construction of gender identities and roles, the interconnectedness of militarism and sexism, and the complex relationship of colonialism, nationalism and feminism, integral parts of IR [international relations] scholarship.

However, it should be noted here that, as Tickner (1992: 5-6) points out, 'making gender an integral part of international relations theory' has twofold connotations in feminist discourse, in that it is perceived either as the incorporation of gender, which leads to Gender and International Relations, or as the reconstruction of international relations theory, which poses the question of Gender in International Relations. For Tickner, the difference between these two connotations, or the difference between 'and' and 'in', lies in the fact that the latter states from the outset that gender has always been an integral part of international relations. Unmasking the patriarchal feature of international relations theory, and then attempting to reconstruct the fundamental categories of that theory, such as security, production, anarchy, allows, the engendering of international relations theory. Thinking of gender in international relations makes it possible to see the equation of 'what is human with what is masculine', and Tickner (1992: 5) thus states boldly that

Nowhere is this more true than in international relations, a discipline that, while it has for the most part resisted the introduction of gender into its discourse, bases its assumptions and explanations almost entirely on the activities and experiences of men.

This implies that engendering international relations theory begins by displaying its masculinist feature, which enables feminist discourse to 'situate' that theory in patriarchal authority that arises from the equation of 'human' with 'masculine' thereby suggesting that what is called 'logocentricism' is in fact 'androcentricism'. Tickner thus argues that international relations theory has been overdetermined by the privileged role assigned to the sovereign male subject and has operated on the basis of the hegemonic discourse of masculinity. Moreover,

[h]egemonic masculinity is sustained through its opposition to various subordinated and devalued masculinities, such as homosexuality, and, more importantly, through its relation to various devalued femininities. Socially constructed gender differences are 
based on socially sanctioned, unequal relationships between men and women that reinforce compliance with men's stated superiority. Nowhere in the public realm are these stereotypical gender images more apparent than in the realm of international politics, where the characteristics associated with hegemonic masculinity are projected onto the behavior of states whose success as international actors is measured in terms of their power capabilities and capacity for self-help and autonomy.

(Tickner, 1992: 6)

Hegemonic masculinity therefore refers to a discourse which produces 'a type of culturally dominant masculinity' and whose self-definition depends on the construction of its binary opposition, devalued femininities, that is, the construction of its Other. Thus, like postmodernism, feminist discourse conceives of modernity as an understanding of the world based on the self/the Other dichotomy and through a set of binary dichotomies, such as public versus private, objective versus subjective, reason versus emotion, in which the first of each pair characterizes masculinity, the second femininity. Hence, international relations theory, framed in these binary oppositions, clearly rests upon and supports patriarchal authority, and reproduces patriarchal social and political order. Engendering international relations means, on the one hand, resisting this patriarchal authority, and on the other, identify[ing] the as yet unspecified relation between the construction of power and the construction of gender in international relations' (Tickner, 1992: 19). In the second respect, feminist discourse goes beyond postmodernism, insofar as it also attempts to reconstruct international relations theory and its fundamental categories by dismantling the binary dichotomies and by recognizing gender difference as central to theorizing international relations. In this sense, the feminist simultaneous de- and re-construction of international relations theory provides a 'situated' and concrete notion of difference rather than that which is abstract, and it is in this context that feminist discourse proves to be a significant device by which to resist the process of othering in international relations theory.

However, like postmodernism, feminist discourse in its liberal version faces a crucial dilemma, that is, it tends to present the western white woman as the transcendental subject, a universal point of departure from which counter-claims to patriarchy are supposed to be made. In other words, as Alcoff (1989:34) correctly points out, 'the dilemma facing feminist theorists today is that our very self-definition is grounded in a concept [that of woman] that we must deconstruct and de-essentialize in all of its aspects'. That feminism attempts to reveal the destructive character of the essential and universal 'man' as the paradigmatic object of the patriarchal discourse should also render problematic any feminist 
analysis that has the essential, universal 'woman' as its subject (Harding, 1989: 16-17). For an attempt to construct a universal theory of human experience and global solutions based on such experience could easily lead, within feminism, to the replication in theory and practice of the way in which the patriarchal discourse functions.

The need to de-essentialize the concept of woman finds its clearest expression in the objections and skepticism raised by Third World women and women of color to liberal feminist discourse. For instance, the introduction of the term 'double jeopardy' implies the difference that occurs in the process of the subjugation of black women through sexist and racist practices and makes it clear that the concept of 'black woman' contains not only sexual inequalities or oppression but also racial discriminations. ${ }^{3}$ Not to recognize the double jeopardy that women of color have been subjected to leads to the appropriation of difference into sameness and marks the universalizing and Eurocentric tendency that the concept of woman involves. King (1988: 57) argues in this respect that

the phrase that, 'the personal is the political' not only reflects a phenomenological approach to women's liberation - that is, of women defining and constructing their own reality, but it has also come to describe the politics of imposing and privileging a few women's personal lives over all women's lives by assuming that these few could be prototypical.

In a similar way, the analytical priority and prototypical quality attributed to the concept of woman is questioned in terms of its implication for the Third World and development. For instance, within the context of liberal feminist writing about Third World women, Mohanty (1991a: 71) raises the question of "what happens when [the] assumption of "women as oppressed group" is situated in the context of Western feminist writing about third world women?' and suggests that one could see a 'colonialist move' in which 'third world women never rise above the debilitating generality of their "object" status', while western feminists act as 'the true "subjects" of this counter history'. It is asserted, thus, that liberal feminist discourse in its monolithic thinking about the Third World proves to be as Eurocentric as the western modern discourses of development. As Minh-ha (1989) claims, the perception of the 'Third World woman' as a unified category dictates both the colonizing tendencies in the concept of the woman and the linguistic exclusion of referents specific to 'Third World female persons'. Spivak (1987: 136) suggests in this respect that 'in order to learn ... about Third World women ... the immense heterogeneity of the field must be appreciated, and the First World feminist must learn to stop feeling privileged as a woman'.

What is being objected here is the neutralized nature of difference in liberal feminist discourse from race, ethnicity, and culture and its 
manifestation in 'the continued degradation of Third World women'. If the neutralization of difference constitutes 'the very kind of colonizedanthropologized difference the master has always granted his subordinates', then liberal feminist discourse, like postmodernism, encounters the same problem of being integral to western universalism and Eurocentricism (Minh-ha, 1989: 19). This possibility that feminist discourse faces, even though it itself constitutes the Other of the modern self, indicates, on the other hand, the very difficulty with theorizing otherness, dealing with difference, accommodating diversity, and coming to terms fully with the spatial, temporal construction of subjectivity. It has been argued, in this context, that in order for feminist discourse to be able to claim relevance in terms of theorizing the Other, it is crucial to abandon the universalizing assumptions, analytical certainties, and foundational grounds derived from the concept of woman and to recognize the plurality of differences in the identity of woman (Sylvester, 1994). This means, first, that there is no uniform condition of existence of woman; and second, that there is no coherent epistemological feminist standpoint to be privileged but multiple standpoints, multiple discourses of the very partial, spatial and multiple nature of women's realities of gender, race, ethnicity. Harding (1989: 17) thus suggests that 'once essential and universal man dissolves, so does his hidden companion, woman. We have, instead, myriads of women living in elaborate historical complexes of class, race, and culture.' This suggestion also leads to locating difference in global history as a way of resisting the universalist and Eurocentric operation of western modernity. It is here that postcolonial criticism becomes a crucial device for both the deconstruction of modernity and the construction of an alternative subjectivity based on difference.

\section{POSTCOLONIAL CRITICISM AND LOCATING DIFFERENCE}

In his attempt to problematize the notion of difference, Homi Bhabha (1989) asserts that not only western logocentricism, but also theoretical discourses 'committed to the articulation of difference', such as postmodernism and feminism, have tended to marginalize racial/cultural/ historical otherness in their modes of representation of otherness. Therefore, for Bhabha, it is crucial to question such modes of representation in order to reveal 'the limits of Western metaphysical discourse'. Although these discourses take an anti-Eurocentric (or ethnocentric) stance, what is aimed is to prove the limits of western logocentricism through the recognition of otherness 'as a symbol (not sign) of the presence of significance and differance' (Bhabha, 1989: 151). What is denied here is the need to explore the historical and discursive construction of otherness as a 'differential sign', that is, an exploration of differential materiality and history of colo- 
nial culture. This means that the place of otherness, which was fixed as the Other of the modern self in western logocentricism, remains as fixed in anti-Eurocentric stance, but this time as 'the limit-text' of the West, as anti-West. ${ }^{4}$ In this respect, addressing the question of Eurocentricism within the context of theoretical discourses whose objective is to articulate difference, one could not only explore the limits of logocentricity but also, and more important, investigate the possibilities of constructing critical strategies with which to create an ethical space for the Other to speak. Underlying postcolonial criticism is therefore the intention of reconstructing the discourse of cultural difference in such a way that requires a radical revision of the way in which we think about subjectivity and identity. ${ }^{5}$

The main objective of postcolonial criticism is therefore to challenge:

how imperial centers of power construct themselves through the discourse of master narratives and totalizing systems. They [postcolonial theorists] contest monolithic authority wielded through representations of 'brute institutional relations' and the claims of universality. Postcolonial theorists offer resistance to social practices that relegate Otherness to the margins of power; they interrogate how centers of power and privilege are implicated in their own politics of location as forms of imperializing appropriation; and, of crucial importance, postcolonialism contests the dominant Eurocentric writing of politics, theory, and history.

(Giroux, 1992: 21)

Central to this contestation is to seek effective ways of exposing the operation of modernity in the silencing and oppressing of the colonial Other and of dismantling its signifying systems of modernization, reason, and progress. For this reason, in postcolonial criticism, the object of analysis is focused upon the process of othering as an attempt to 'put the Other into discourse' as a mirror image of the modern self, in order not only to deconstruct it to demonstrate its Eurocentric foundation and to challenge 'teleologies of modernization and their constituent themes of Reason and Progress' (Prakash, 1990: 384), but also to construct a possibility of the politics of difference as a link among hitherto subordinated and marginalized subject-positions of race, ethnicity, gender. Thus, by regarding culture as a signifying practice and by locating otherness in the process of the globalization of modernity, postcolonial criticism reconstructs the notion of difference as a political resource for the construction of alternative subjectivities (Ashcroft et al., 1989; Khare, 1992; Mani and Frankenberg, 1993; West, 1990).

To delineate the way in which the deconstruction and (re)construction of the politics of difference is carried out in postcolonial criticism, it is necessary to refer briefly to Edward Said's work on Orientalism, since it 
provides what can be called a 'paradigm-constitutive' framework on which the postcolonial interrogation of western modernity is built. ${ }^{6}$ Said's genealogical study of Orientalism is a contrapuntal reading 7 of western discourses on the Orient in such a way as to reveal that the distinction drawn between the Occident and the Orient, with which universally dichotomizing western historicism operates, forms a historically specific discourse of power/knowledge. Said is concerned with delineating how this discourse works in three specific (and interrelated) locations. Orientalism refers to (a) the practice of teaching about the Orient, (b) 'a style of thought based upon an ontological and epistemological distinction made between "the Orient" and "the Occident",' and (c) 'a corporate institution for dealing with the Orient'. While (c) indicates the historical specificity of Orientalism, that is, the interconnection between Orientalism and European colonial expansion from the eighteenth century onwards, ${ }^{8}(\mathrm{a})$ and $(\mathrm{b})$ reveal the power/knowledge basis of it, that is, the way in which the Orient is represented through and deployed in the West, which in turn made it possible for European culture to 'manage, even produce, the Orient politically, sociologically, militarily, ideologically, scientifically, and imaginatively during the post-Enlightenment period'. In this sense, what Orientalism constructs and demonstrates is the linkage between a style of thought and institutions of power, which finds its clearest expression in Said's suggestion that

insofar as it [orientalist discourse] was a science of incorporation and inclusion by virtue of which the Orient was constituted and then introduced in to Europe, Orientalism was a scientific movement whose analogue in the world of empirical politics was the Orient's colonial accumulation and acquisition by Europe.

(Said, 1989: 208)

An investigation of the construction of this linkage leads Said to analyze the mode of operation of cultural hegemony of a style of thought, which for him constitutes the discursive formation of imperialism, an interdependency between culture and Empire. He states within this context that:

Under the general heading of knowledge of the Orient, and with the umbrella of Western hegemony over the Orient during the period from the end of the eighteenth century, there emerged a complex Orient suitable for study in the academy, for display in the museum, for reconstruction in the colonial office, for theoretical illustration in anthropological, biological, linguistic, racial, and historical theses about mankind and universe, for instance of economic and sociological theories of development, revolution, cultural personality, national and religious character. Additionally, the imaginative examination of things Oriental was based more or less 
exclusively upon a sovereign Western consciousness out of whose unchallenged centrality an Oriental world emerged, first according to general ideas about who and what was an Oriental, then according to a detailed logic governed not simply by empirical reality but by a battery of desires, repressions, investments, and projections.

(Said, 1987: 7-8)

Here the crucial question is that of representation. Following Antonio Gramsci (with respect to his conception of hegemony which Said articulates as 'a cultural leadership') and Michel Foucault (with respect to his notion of 'power/knowledge' which Said uses to present Orientalism as a discourse on the basis of which the Orient was constructed as a fixed identity with a timeless essentialism), Said suggests that the distinction between the Occident and the Orient, which has been made at the levels of ontology and epistemology, manifests itself in the systematic objectification and discursive construction of the Orient not only as an object of study but also as a subject 'integral' to western hegemony. Thus the Orient functions as an integral element of the very constitution and the definition of the West, as being its contrasting image. 'The Orient is an integral part of European material civilization and culture. Orientalism expresses and represents that part culturally and even ideologically as a mode of discourse with supporting institutions, scholarship, imaginary, doctrines, even colonial bureaucracies and colonial style' (Said, 1978: 2).

Having briefly outlined the basic premises of Said's genealogical study of Orientalism, it is possible to see its significance as a 'paradigmconstitutive' attempt for the deconstruction of 'universalizing historicism' as well as for the restructuring of historiography. Said's work makes a significant contribution in three fundamental ways. First, it shows that Eurocentricism is the precondition of the Orientalist image of the Other. In this sense, Said provides a conception of the Other as a discursive construct, which enables us to break radically with the appropriation of the Other as either an empirical/cultural being or a being in itself. Second, the working of orientalist discourse indicates that culture is not a totality of shared values and meaning but a practice, a signifying practice through which meaning is socially constructed. That the Orient is constructed as an integral element of the Occident is indicative of how culture works as a signifying practice. To conceptualize culture in this way unearths what the notion of cultural diversity hides - the hegemony of the modern self, which in turn makes it possible to consider cultural difference in relational terms. Third, and as a logical consequence of the first and the second, Said's work provides a radical critique of the typological and essentialist understanding of history in which the defining characteristics of western modernity constitute the primary point of reference for the analysis of international relations in general, 
other cultures in particular. Said's critique of what we called 'the Gemeinschaft-Gesellschaft problematic' as Eurocentric and Orientalist applies equally both to the classical sociological discourses of Marx, Weber, and Durkheim and the theories of development articulated by modernization, political development, and neorealist theories. Likewise, as we have seen, when read from the angle of Eurocentricism, postmodern and liberal feminist discourses tend to become problematic as they fail to break radically with this problematic.

However, Said's work is not without problems. These problems, as Young (1990: 119-41) argues, have a common origin, that is, they all stem from Said's lack of attention to the 'ambivalent' character of the relationality of the Occident and the Orient. More specifically, Said fails to account for the interaction between the representation of the Orient, which concerns the invention of the Orient by Europe, and the actualization of that representation, which concerns the moment when, or the process in which, such representation becomes an instrument in the service of colonial power, conquest, occupation, and administration. The point here is that when the latter is subsumed into the former, it becomes difficult, if not impossible, to see a profound ambivalence towards the otherness, the way in which the colonized is constructed by orientalist discourse. In this context, Said's suggestion that the West depends on its colonies for self-definition does not say much about the process in which orientalist discourse operates in the colonized world. In other words, whereas Said's genealogical study of Orientalism shows powerfully how the Eurocentric mode of representation works as a discourse of power/ knowledge, his study falls short in providing an account of the so-called Orient, that is, the working of orientalist discourse within the Orient, since he does not engage in an attempt to investigate the process in which the colonial subject is historically constructed. As Bhabha (1984: 123) notes, 'the representation may appear to be hegemonic, but it carries within it a hidden flaw invisible at home but increasingly apparent abroad when it is away from the safety of the West'.

This general theoretical problem manifests itself in and gives rise to two interrelated problems. First, Said offers a totalizing vision of the Orient which does not take into account not only differences within the Orient but also alterity, which is, the possibility of resistance to orientalist discourse. Thus, orientalist discourse appears to be monolithic, undifferentiated, and uncontested. Contrary to Said, Bhabha (1989) argues that the production of a representation of the Other is by no means straightforward as in the case of the process of colonial stereotyping of the Other and its culture. For Bhabha, the ambivalence of colonial stereotyping can be seen in the hybrid character of the colonial subject which indicates the incomplete articulation of colonial and native knowledges, in which the fixing of the colonial subject by orientalist discourse is never 


\section{ARTICULATING DIFFERENCE}

achieved. This means that insofar as colonial discourse results in the production of not a fixed colonial identity but 'hybridization', such hybridization also reveals the possibility of undermining colonial authority, because it enables a form of subversion that turns the discursive conditions of dominance into the grounds of intervention'. At the level of representation, this also means that Said's attribution to orientalist discourse an undifferentiated and uncontested quality is a theoretical simplification, for it does not see that the repetition of the epistemological and ontological distinction drawn between the Occident and the Orient takes different forms, depending upon its ambivalence and the native resistance to colonial domination.

Second, it can be argued that Said's lack of attention to the actual operation of orientalist discourse in the so-called Orient makes him unable to see the significant sites at which Orientalism operates, and also to deal with the appropriation of orientalist discourse in colonial society, which is of significance to a critical interrogation of what has come to be known as 'the Third World nationalism'. As for the first, it has been argued that Said fails to see the crucial role the image of woman plays in the way in which the Orient was represented as an essentialized Other. Marcus (1992) argues in this context that the documentation by Said of the European obsession with women and sexuality is only 'incidental', in that it serves the purpose of demonstrating the construction of the Orient as an objectified other, 'unable to speak as an individual and known only through the European writer'. Marcus goes on to show, with respect to the gender hierarchy in Turkey, that the important role of women and sexuality in the construction of orientalist discourse on the East has not only textual (the mode of representation) but also sociological significance (the discursive and historical construction of gender) to the totality of orientalist knowledge. Seen in this mode, Marcus concludes that insofar as the western male represents both ravisher and seeker of wisdom, while the wisdom is both gendered female and sexed, such representation reveals the fact that "the western "orient" is indeed a gendered, female orient'.

Similarly, Spivak's important essay, 'Can the subaltern speak?' (1988), demonstrates in the context of sati (widow burning) that '[British] imperialism's image as the establisher of the good society is marked by the espousal of the woman as object of protection from her own kind'. For Spivak, the non-identity of the woman as 'object of protection' in the process of the abolition of sati in India indicates, first, the importance of the category of woman for the representation of the modern self as a civilizing subject of the uncivilized East, and second, the objectification of the woman in that she is denied a space to speak, even when she is the subject of the practice (such as sati) under interrogation. Thus, sati is represented through interlocking discourses, such as 'White men are 
saving brown women from brown men' and 'The women wanted to die', which in turn meant 'the subaltern cannot speak'. Following Spivak's account of sati, Yegenoglu (1994) argues that the process of unveiling or veiling women was central to the nationalist project of modernization and anti-modernization in Turkey and Algeria. Just as in the case of sati, this process was carried out in these societies by a discourse which does not contain any voice of women: a discourse which Yegenoglu terms a 'veil fantasy'. What these examples illustrate is that orientalist discourse is consolidated not only through the representation of the Other as both the oriental passive subject and the object of the transcendental occidental studying subject, but also through specific relations of ruling (colonial practices) involving both forms of knowledge and institutions of sexual, racial, and class/caste domination.

In this context, Mohanty suggests that in order to understand both the operation of colonial rule through orientalist discourse and the resistance to such ruling, it is necessary to focus on:

(1) the ideological construction and consolidation of white masculinity as normative and the corresponding racialization and sexualization of colonized peoples; (2) the effects of colonial institutions and policies in transforming indigenous patriarchies and consolidating hegemonic middle-class cultures in metropolitan and colonized areas; and (3) the rise of feminist politics and consciousness in this historical context within and against the framework of national liberation movements.

(Mohanty, 1991b: 15)

What Mohanty's suggestion means in terms of Said's account of Orientalism is that it minimizes the significance of the second and third aspects, which stems from his lack of attention to concrete colonial practices. This in turn makes problematic Said's account of the Orient with respect both to its preoccupation with textuality and to his total neglect of the question of resistance to colonial rule. The recognition of the significance of woman produces a crucial shift from textuality to a detailed analysis of colonial rule, from representation to a genealogical account of the process construction of (colonial) identity, and from regarding orientalist discourse as uncontestable to acknowledging the contradictory and unfixed character of subject positioning in terms of gender, race, ethnicity, and class. In other words, the question of agency is posed as a significant site at which the effective critique of both colonial rule and (nationalist) resistance to it is produced.

Here the specific question is whether or not anti-colonial struggle via nationalist discourse to gain independence is, or has been, able to break with orientalist discourse, that is, the question of resistance which Said completely ignores. This question displays the second above-mentioned 
flaw in Said's account of Orientalism: because Said does not deal with the actual operation of orientalist discourse, he fails to see the strength of that discourse even at the moment it is resisted. In this context, Chatterjee (1986, 1994) suggests that the working of orientalist discourse both at the levels of problematic (the essentialist conception of the Orient) and thematic (an epistemological and ontological distinction between the Occident and the Orient) can also apply to nationalist thought. Chatterjee's important study of nationalist thought as a 'derivative discourse' demonstrates that nationalist discourse that has been regarded as the main form of resistance to western colonialism is in fact a product of Orientalism, a reversed Orientalism, in which it acts on the basis of the categories produced by Orientalism. ${ }^{9}$ Underlying Chatterjee's point is the observation that:

nationalist thought, in agreeing to become 'modern,' accepts the claim to universality of this 'modern' framework of knowledge. Yet it also asserts the autonomous identity of a national culture. It thus simultaneously rejects and accepts the dominance, both epistemic and moral, of an alien culture.

(Chatterjee, 1986: 11)

To delineate the way in which this simultaneous rejection and acceptance of dominance occurs in nationalist discourse, Chatterjee argues that at the level of problematic, nationalist thought presents a reverse Orientalism, in which the 'object' is still the essentialist timeless Oriental, but this time it acquires subjectivity, acts as an active, participating, sovereign, and autonomous subject rather than passive and non-participating. At the level of problematic, nationalist thought adopts the same typological understanding of history constructed on the basis of an epistemological and ontological distinction between the Occident and the Orient. To display the orientalist operation of nationalist thought is important for Chatterjee to demonstrate the relationship between culture, power/ knowledge, and change. At the heart of the contradictory character of nationalist thought lies the fact that it operates within the framework of knowledge 'whose representational structure corresponds to the very structure of power nationalist thought seeks to repudiate' (Chatterjee, 1986: 38). Chatterjee concludes that nationalist thought as a derivative discourse is indicative of the theoretical insolubility of the national question in colonial society within the framework of nationalism. More specifically, nationalist thought opposes colonial rule, but it lacks the ability to break with reason, to challenge via its own discourse the legitimacy between reason and capital, and to act as the antagonist of universal Reason in history. What nationalist thought does is to absorb the political life of the nation into the body of the state, by representing the latter as the representative of the nation, 'the principal mobilizer, planner, 
guarantor and legitimator of productive investment' (Chatterjee, 1994: 202-3). However, this absorption is achieved in the very name of Reason, and is by no means contradictory to the operation of Orientalism, and it is in this context that it can be argued that the ending of the colonial rule as the political success of nationalism does not mean a resolution of the contradictions of nationalist thought. It is for this reason that Chatterjee concludes his study by proposing that

much that has been suppressed in the historical creation of postcolonial nation-states, much that has been erased or glossed over when nationalist discourse has set down its own life history, bear the marks of the people-nation struggling in an inchoate, undirected and wholly unequal battle against forces that have sought to dominate it. The critique of nationalist discourse must find for itself the ideological means to connect the popular strength of those struggles with the consciousness of a new universality, to subvert the ideological sway of a state which falsely claims to speak on behalf of the nation and to challenge the presumed sovereignty of a science which puts itself at the service of capital, to replace, in other words, the old problematic and thematic with new ones.

(Chatterjee, 1986: 169)

The key conclusion that can be extrapolated from Chatterjee's critique of nationalist thought, as well as Bhabha's insistence on the ambivalent character of colonial discourse and Spivak's point that the subaltern cannot speak, is that to modify Said's account of Orientalism it is necessary to pose the question of agency. In other words, the critique of orientalist discourse should concern itself not only with the process of what Said calls the process of orientalizing the Orient, that is, the Eurocentric image of the Other as a discursive contract, but also with theorizing the colonial subject which is the precondition of recognition of the Other as difference. It can be argued here that it is this twofold concern that constitutes postcolonial criticism as a powerful means by which to produce the possibility of the politics of cultural difference. Postcolonial criticism's attempt to rewrite colonial history not only helps discover the significance for orientalist discourse of the constitution of colonial identity through the racialization and sexualization of colonized people. It also demonstrates that the constitution of identity was never complete, nor was it fixed, but involved what Bhabha (1992a) calls the 'ambivalent character'. The latter point indicates a crucial shift in regard to the conception of the Other, from a discursive construct to difference as a site where identity is neither continuous nor continuously interrupted but constantly framed between the simultaneous vectors of similarity, continuity and difference' (Hall, 1990: 206). This means that to see colonial identity as fixed can only reproduce the hegemony of orientalist discourse, as in the case of nationalist thought, 


\section{ARTICULATING DIFFERENCE}

and fails to see the relational character of the interaction between the colonizer and the colonized that was never straightforward but involved the resistance of the colonized to be fixed, which produced what Bhabha (1989) called 'hybridity' or 'mimicry' as 'the moments of civil disobedience within the disciple of civility: signs of spectacular resistance'. The advantage of this relational idea of identity is that it leads to conceiving of difference as a political resource. To think of difference in terms of its construction as unfixed provides a basis for discovering new ways of understanding identity/difference, rather than essentializing difference as an expression of a fixed identity. It is in this way that the relational idea of identity produces a resource by which the points of resistance to relations of inequality and domination are multiplied.

\section{CONCLUSION}

In the light of the above discussion of postmodernism, feminism, and postcolonial criticism, it can be suggested that an empathetic cooperation among these discourses is central to articulating difference into IPE in such a way that otherness becomes omnipresent from the beginning in any attempt to grasp the functioning of global modernity. Postmodern deconstruction and the move away from binary oppositions between self and the Other opens up a new way of understanding political economy and creates a new set of methods for political economic research. What postmodernism does is to enable us to see global modernity as a process of othering and at the same time to approach political economy from the problematic of identity/difference. Yet, the postmodern notion of difference appears to be a philosophical construct that needs to be situated and located in a concrete historical context, whether it be the patriarchal or the Eurocentric operation of global modernity. To historicize identity is to analyze the construction of the Other historically, and therefore to resist the practice of inclusion/exclusion in its concrete and historical operation (J.W. Scott, 1992: 26). This means that postmodernism in its constructive mode needs to be empathetic to different theories and empirical referents and should learn from feminism and postcolonial criticism, if it is to provide not only an effective critique of modernity but also an adequate ground for the articulation of 'an ethics of the self' into the realm of IPE.

Likewise, an empathetic cooperation between feminism and postcolonial criticism enables each discourse to reconstruct itself in such a way as to situate the problematic of identity difference at the intersection of race, ethnicity, gender, and class. While feminism learns from postcolonial criticism the need to historicize identity and recognize its multiple points of construction, postcolonial criticism needs feminism to see that the 'woman question' constitutes a significant site at which both Orientalism and a resistance to it operate. More important, the empathetic cooperation 
THEME SECTION: REPRESENTATION IN IPE

between these two discourses makes it possible for us to come fully to terms with the relational idea of identity. The importance of a relational idea of identity, constructed through empathetic cooperation, is that it encourages us to conceive of difference both as a political resource by which to resist the myriad of relations of inequality and domination and as 'an ethics of the self' on which to build a democratic vision of community (McNay, 1992: 112-13). It is through a relational idea of identity that IPE creates a space for those whose experiences have been marginalized and served simply as an object of theory to act as active subjects of political economic research. Herein lies the significant contribution that the problematic of identity/difference makes to our understanding of international political economy.

\section{NOTES}

This paper was first presented at the annual meeting of the International Studies Association, Acapulco, Mexico, March 1993. I am grateful to Craig N. Murphy who read this paper a number of times, from its first draft to its final version, and made many extremely helpful and valuable suggestions, most of which I have adopted. I would also like to thank Jane Jenson and George Ross for their valuable comments and suggestions. The paper was written as part of my postdoctoral research in the Department of Political Science of Wellesley College, Massachusetts, and was supported by Social Sciences and Humanities Research Council of Canada, Ottawa.

1 Murphy and Tooze regard neorealism as constitutive of the IPE orthodoxy. In this paper, I also include the Wallersteinian world-systems theory as an example of the IPE orthodoxy, insofar as it resists difference, leads to the dissolution of difference into identity, particular into universal, and regards otherness as an cultural object. Although these two paradigmatic positions differ in their approach to IPE, they share the same utilitarian logic and epistemological/ontological procedures. For detail, see Bergesen (1990) and Keyman (1994a). For neorealism and world-systems theory, see Waltz (1979), Keohane (1984), Wallerstein $(1983,1991)$.

2 These paradigms of culture are extrapolated from my reading of Williams (1983) and Bocock (1992).

3 See Beale (1979: 89-109). A very good historical account of the problem of race in feminism was offered by Ware (1992: Parts, 2, 3, and 4).

4 To illustrate this point, Bhabha (1989: 152) gives as an example Derrida and his strategy of deconstruction.

Derrida, for example, in the course of his Positions interview, tends to fix the problem of ethnocentricity repeatedly at the limits of logocentricity, the unknown territory mapped neatly on the familiar, as presuppositions inseparable from metaphysics. Such a Position cannot lead to the construction or exploration of other discursive sites from which to investigate the differential materiality and history of colonial culture.

See Derrida (1981) for the strategy of deconstruction.

5 Edward Said's (1993) 'contrapuntal analysis' of western culture, Gayatri Spivak's (1987) characterization as 'an interruptive formation' of the relation- 


\section{ARTICULATING DIFFERENCE}

ality of race, gender, class, and nation, and Homi Bhabha's (1992a and 1992b) postcolonial translation of western modernity are all intended to demonstrate the need to rethink the discourse of cultural difference.

6 For instance, O'Hanlon and Washbrook (1992) consider Orientalism to be a paradigm for the study of non-European histories and cultures on the basis of the theoretical perspectives provided by post-structuralism and postmodernism. Likewise, Hentsch (1992) argues that 'Said's book has become the corridor through which all examination and discussion of Orientalism must pass'.

7 Said (1993) defines contrapuntal reading as a strategy, or criticism, of reading of the modern self/the Other dichotomy as intertwined and overlapping, that is, reading texts from the metropolitan center and from the peripheries contrapuntally, neither according to the privilege of objectivity to our side nor the encumbrance of subjectivity to theirs. According to JanMohamed (1992), Said's contrapuntal reading derives from his intellectual characteristic as a 'specular border intellectual' who 'is the subject neither of the host culture or the dominant class ... nor of the "home" culture or the subaltern class', but whose critique 'is articulated from the neutrality of the border'.

8 This historical specificity, attributed to Orientalism in terms of its linkage to colonial expansion, differentiates Said's account from those that are focused on the classical origins of orientalist discourse in order to suggest that Orientalism is 'the patrimony of ancient philosophy (Plato and Aristotle) in the West'. Said thinks that imperialism (colonial expansion) constitutes a fundamental point of rupture in the way in which orientalist discourse operates. For detail, see Mani and Frankenberg (1985).

9 Chatterjee correctly observes that although his analysis of nationalism as a derivative discourse deals specifically with the Indian case, it also applies to other nationalist resistance movements. For the application of Chatterjee's theory of nationalism to Turkey, see Keyman (1994b). 